\title{
QUALITY OF LIFE AND ITS CORRELATES IN ALCOHOL DEPENDENT MALES: REHAB INPATIENTS AND SHELTER OR HOSTEL HOMELESS PERSONS
}

JAKOŚĆ ŻYCIA I JEJ KORELATY U MĘŻCZYZN

UZALEŻNIONYCH OD ALKOHOLU - LECZONYCH STACJONARNIE ODWYKOWO I BEZDOMNYCH PRZEBYWAJĄCYCH W SCHRONISKU LUB HOSTELU

\author{
Damian Czarnecki ${ }^{1}$, Marcin Ziółkowski ${ }^{1}$, Jan Chodkiewicz ${ }^{2}$, Michał Danek ${ }^{3}$, Beata Łangowska-Grodzka ${ }^{1}$, \\ Ludmiła Zając-Lamparska ${ }^{4}$ \\ ${ }^{1}$ Department of Psychiatric Nursing, Faculty of Health Sciences, Collegium Medicum in Bydgoszcz, Nicolaus Copernicus \\ University in Torun, Poland \\ ${ }^{2}$ Department of Health Psychology, Institute of Psychology, University of Lodz, Poland \\ ${ }^{3}$ Department of Psychiatry, Faculty of Medicine, Collegium Medicum in Bydgoszcz, Nicolaus Copernicus University in Torun, Poland \\ ${ }^{4}$ Department of Human Development, Kazimierz Wielki University in Bydgoszcz, Poland \\ ${ }^{1}$ Zakład Pielegniarstwa Psychiatrycznego, Collegium Medicum w Bydgoszczy, Uniwersytet Mikołaja Kopernika w Toruniu, Polska \\ ${ }^{2}$ Zakład Psychologii Zdrowia, Instytut Psychologii, Uniwersytet Łódzki, Łódź, Polska \\ ${ }^{3}$ Katedra Psychiatrii, Wydział Lekarski, Collegium Medicum w Bydgoszczy, Uniwersytet Mikołaja Kopernika w Toruniu, Polska \\ ${ }^{4}$ Katedra Psychologii Rozwoju Człowieka, Uniwersytet Kazimierza Wielkiego w Bydgoszczy, Polska
}

Alcohol Drug Addict 2017; 30 (1): 41-58 DOI: https://doi.org/10.5114/ain.2017.68344

\begin{abstract}
Introduction: Alcohol abuse leads to a lot of mental, somatic and social problems and may also be a cause of homelessness. These problems are often correlated with a decrease in alcohol dependent persons' quality of life including their capacity to handle everyday issues and the ability to obtain medical care. The purpose of the study was to compare the quality of life of alcohol dependent persons:
\end{abstract}

Streszczenie

Wprowadzenie: Nadużywanie alkoholu jest przyczyną zaburzeń w wielu obszarach funkcjonowania jednostki. Zdarza się, że prowadzi do bezdomności, która skupia w swym spektrum głębokie problemy psychiczne, fizyczne i społeczne. Tym samym w przebiegu uzależnienia od alkoholu, a szczególnie w bezdomności, jakość życia obniża się, co może pogarszać radzenie sobie, a w konsekwencji utrudniać uzyska-

Correspondence to/Adres do korespondencji: Damian Czarnecki, Zakład Pielęgniarstwa Psychiatrycznego, Collegium Medicum, 1 Ignacego Łukasiewicza St., 85-821 Bydgoszcz, Poland, phone: +48 5258542 82, fax: +48 52585 5903,

e-mail: czarneckidamian@cm.umk.pl

Authors' contribution/Wkład pracy autorów: Study design/Koncepcja pracy: D. Czarnecki, M. Ziółkowski / Data collection/

Zebranie danych: D. Czarnecki / Statistical analysis/Analiza statystyczna: D. Czarnecki, M. Ziółkowski, J. Chodkiewicz, L. Zając-Lamparska / Data interpretation/Interpretacja danych: D. Czarnecki, M. Ziółkowski, J. Chodkiewicz, M. Danek, B. Łangowska-Grodzka, L. Zając-Lamparska / Acceptance of final manuscript version/Akceptacja ostatecznej wersji: M. Ziółkowski, J. Chodkiewicz / Literature search/ Przygotowanie literatury: D. Czarnecki, M. Danek, B. Łangowska-Grodzka / Funds collection /Pozyskanie finansowania: D. Czarnecki

No ghostwriting and guest authorship declared/Nie występują zjawiska ghostwriting i guest authorship.

Submitted/Otrzymano: 09.12.2016• Accepted/Przyjęto do druku: 02.03.2017 
rehab centre inpatients and homeless subjects, and also to evaluate correlations between their quality of life and chosen clinical variables, social support and barriers in obtaining alcohol dependence treatment.

Material and methods: The study investigated 60 inpatients treated for alcohol dependence and 29 alcohol dependent homeless persons in shelter and hostel accommodation. All subjects were assessed using the following psychometrically scales: SF-36, SADD, BDI, MMSE, STAI and an interview questionnaire.

Results: It was observed that rehab inpatients scored slightly worse results than homeless persons with regard to general mental functioning and to limitations in fulfilling life roles due to emotional problems. That is compared to homeless subjects, rehab inpatients had lower scoring of emotion subscale (E) and mental component summary (MCS) of the SF-36. It was suggested that low values of physical component summary (PCS) of SF-36 in rehab inpatients were associated with anxiety and somatic symptoms, and low values of mental component summary (MCS) with intensive anxiety symptoms, depression and other psychic problems. The observed low PCS values in homeless subject group were associated with duration of alcohol drinking, and low MCS values with better social support, intensive depression symptoms, and psychic problems.

Conclusions: Despite socio-demographic and clinical differences between studied groups, rehab inpatients and homeless subjects had similar evaluation of their quality of life in SF-36 scale scoring.

Keywords: Quality of life, Alcohol dependence, Homelessness nie pomocy medycznej, np. dotyczącej leczenia odwykowego. Celem badań było porównanie poziomu jakości życia dwóch grup mężczyzn uzależnionych od alkoholu - leczonych stacjonarnie odwykowo i bezdomnych, a także ocena relacji między jakością życia a wybranymi zmiennymi klinicznymi, liczbą źródeł wsparcia społecznego oraz liczbą barier w dostępie do leczenia odwykowego w badanych grupach.

Materiał i metody: Badania przeprowadzono w grupie 89 mężczyzn uzależnionych od alkoholu - 60 pacjentów leczonych stacjonarnie odwykowo i 29 osób bezdomnych przebywających w schronisku lub hostelu. W badaniach zastosowano następujące narzędzia: SF-36, SADD, BDI, MMSE, STAI oraz kwestionariusz do oceny barier w leczeniu odwykowym.

Wyniki: U pacjentów hospitalizowanych na oddziale odwykowym zaobserwowano nieznacznie gorsze niż u osób bezdomnych wyniki ogólnego funkcjonowania psychicznego i związane $\mathrm{z}$ tym nieznaczne ograniczenie pełnienia zadań życiowych z powodów emocjonalnych; mieli oni niższą niż bezdomni punktację w dwóch podskalach SF-36 - emocji (E) i ogólnego funkcjonowania psychicznego (Psy). W grupie osób leczonych odwykowo wykazano, że ogólna jakość funkcjonowania fizycznego SF-36 (Fiz) była niższa z powodu dolegliwości lękowych i somatycznych, a ogólna jakość funkcjonowania psychicznego SF-36 (Psy) niższa ze względu na nasilone objawy lęku, depresji oraz inne problemy psychiczne. U osób bezdomnych niższe wartości podskali Fiz wiązały się z dłuższym czasem picia alkoholu, a niższe wartości Psy z lepszym wsparciem społecznym, nasilonymi objawami depresji i problemami psychicznymi.

Wnioski: Pomimo różnic społeczno-demograficznych i klinicznych pacjenci leczeni stacjonarnie odwykowo i osoby bezdomne podobnie oceniały jakość swojego życia na podstawie skali SF-36.

Słowa kluczowe: jakość życia, uzależnienie od alkoholu, bezdomność

\section{- INTRODUCTION}

Problems associated with alcohol abuse and dependency cumulate over time and greatly hamper not only the individuals but their immediate social circle due to, among other things, being often accompanied by mental disorders; as has been confirmed, chronic alcohol consumption leads to depressive disorder [1]. Another serious conse-

\section{W WROWADZENIE}

Problemy związane z nadużywaniem alkoholu i uzależnieniem od alkoholu stale narastają i stanowią duże obciążenie zarówno dla jednostki, jak i jej otoczenia, m.in. dlatego, że często współwystępują z zaburzeniami psychicznymi - potwierdzono, że przewlekłe spożywanie alkoholu prowadzi do zaburzeń depresyjnych [1]. Inną poważną konse- 
quence of alcohol abuse is numerous somatic problems [2-5]. The physical, psychological and socioeconomic consequences of harmful drinking clearly disturb the individual's functioning, negatively influence the quality of life and may complicate access to medical care [6-8]. According to Stelcer, the quality of life falls where "the hopes and aspirations of the individual are not met by actual experience. The way of improving their level is activities reducing the dissonance between the state expected by the individual and reality" [9]. This situation especially concerns persons with alcohol problems - the illness excludes them from assuming social roles, denies the possibility of gaining help and may even lead to homelessness. This is confirmed by data in the literature, which indicate that alcohol dependency lowers the quality of life [10-12]. Researches demonstrate that the quality of life also depends on the effectiveness of the treatment process understood as, among other things, the reduction of pathological symptoms or deficits of psychomotor functions, improvement in mood and increase in sense of optimism [13].

Alcohol dependency can in itself cause homelessness as well as intensify it, differentiating dependent persons into those whose functioning in many areas of life is more and less disturbed. For example, it has been observed that there are 'shelter' and so called 'street' homeless [14]. Finding oneself in one or other of these groups may depend on the stage of the homelessness process, on the means and coping capacities of the individual (including the sense of the effectiveness of undertaken activities), experienced mental problems (e.g. level of anxiety and depression) [15-17], and on interpersonal relations and the social environment. Also, from the general population, we may distinguish persons on the edge of homelessness (the mentally disordered or dependent), and in their case a lack of change in their lifestyle or health behaviour can inevitably lead to loss of domicile, breakdown of social ties or health or life threatening complications difficult to treat due to numerous limitations with access to professional help.

The complexity of alcohol dependent persons' problems, and those threatened by homelessness or actually homeless encourages us to ask what factors significantly influence the quality of their life and whether they differ in each of these two groups?

It would seem to be advisable to take steps to monitor the threats and factors associated with kwencją nadużywania alkoholu są liczne problemy somatyczne [2-5]. Następstwa somatyczne, psychologiczne i społeczno-ekonomiczne szkodliwego picia alkoholu wyraźnie zaburzają funkcjonowanie jednostki, negatywnie wpływając na jakość jej życia, mogą także ograniczać dostęp do opieki medycznej [6-8]. Według Stelcera jakość życia obniża się tam, gdzie „nadzieje i aspiracje jednostki rozmijają się z aktualnym doświadczeniem. Sposobem poprawienia jej poziomu są działania umniejszające rozdźwięk pomiędzy stanem oczekiwanym przez jednostkę a zastanym" [9]. Sytuacja taka dotyczy szczególnie osób z problemem alkoholowym - choroba wyklucza je bowiem z pełnienia ról społecznych, pozbawia możliwości uzyskania pomocy i niejednokrotnie prowadzi do bezdomności. Potwierdzają to dane z literatury, z których wynika, że uzależnienie od alkoholu obniża jakość życia [10-12]. Jak zauważają badacze, jakość życia zależy także od skuteczności procesu leczenia, rozumianego jako m.in. redukcja objawów chorobowych czy deficytów funkcji psychomotorycznych, polepszenie nastroju lub wzrost poczucia optymizmu [13].

Uzależnienie od alkoholu ze względu na swoją istotę może powodować bezdomność, jak również ją pogłębiać; dzieląc osoby uzależnione na te, których funkcjonowanie $\mathrm{w}$ wielu obszarach życia jest mniej lub bardziej zaburzone, zaobserwowano np., że są bezdomni tzw. schroniskowi lub uliczni [14]. Przynależność do jednej z tych grup może zależeć od etapu procesu bezdomności, a więc od jej zaawansowania, zasobów i możliwości zaradczych jednostki (m.in. poczucia skuteczności podejmowanych działań), doświadczanych problemów psychicznych (np. poziomu lęku i depresji) [15-17] czy relacji interpersonalnych i środowiska. W populacji ogólnej wyróżnia się również osoby z pogranicza bezdomności (z zaburzeniami psychicznymi, uzależnione) - w ich przypadku brak zmiany stylu życia czy zachowań zdrowotnych może nieuchronnie doprowadzić do utraty miejsca zamieszkania, zerwania więzi lub groźnych dla zdrowia i życia powikłań, trudno leczących się ze względu na liczne ograniczenia w uzyskaniu profesjonalnej pomocy.

Złożoność problemów osób uzależnionych od alkoholu i zagrożonych bezdomnością lub bezdomnych skłania do postawienia pytania, jakie czynniki znacząco wpływają na jakość ich życia i czy są one różne w obu tych grupach?

Celowe wydaje się podejmowanie działań monitorujących zagrożenia i czynniki związane z uzależ- 
alcohol dependency, including those occurring among the homeless and assessing those aspects of individual functioning that could decide on commitment to the process of sobriety and emergence from homelessness.

The aim of the study was to compare the level of lifestyle of two groups of alcohol dependent men - rehabilitation inpatients and homeless persons and an assessment of the relation between the quality of life and selected clinical variables and social support as well as the number of barriers in access to dependency treatment.

\section{- Material AND methods}

The study was carried out on 89 males fulfilling the ICD-10 alcohol dependency criteria and who were divided into two groups [18]. The first group was made up of 60 rehab inpatients (average age: 43 , SD $=10)$. The second was 29 homeless men (average age: $45, \mathrm{SD}=12$ ) from two sites - a homeless persons' help centre and a hostel.

We conducted an interview with members of each group that included questions on sociodemographic data (age, marital status, education, source of income and number of sources of social support, e.g. from the family or social services), clinical variables concerning alcohol dependency (time in and depth of alcohol dependency, number of days drinking and number of standard drinks consumed per month over the last six months), number of physical disorders (like high blood-pressure, injuries, liver dysfunction and endocrinological, cardiological, dermatological, neurological disorders, dysfunction of digestive and respiratory system and cardiovascular, thyroid and oncological issues) and also the number of mental disorders like anxiety, listlessness, sadness, aggression, compulsive behaviour, delirium tremens and hallucinations (the questionnaire presented the choice of a number of answers in terms of physical and mental ailments).

The following tools were applied for psychometric assessment:

- The SF-36 (Medical Outcomes Study - MOS, Short Form 36-item) by Ware et al. for subjective assessment of health in the month prior to the study adapted to Polish conditions by Żołnierczyk-Zreda et al. SF-36 is one of the most generally used tools for studying the quality of life determined by state of health. The scale is in the form of 36 questions belong- nieniem od alkoholu, w tym występujące wśród bezdomnych, oraz ocenianie tych aspektów funkcjonowania jednostki, od których może zależeć zaangażowanie $\mathrm{w}$ proces trzeźwienia i wyjście $\mathrm{z}$ bezdomności.

Celem badań było porównanie poziomu jakości życia dwóch grup mężczyzn uzależnionych od alkoholu - pacjentów leczonych stacjonarnie odwykowo i osób bezdomnych - oraz ocena relacji między jakością życia a wybranymi zmiennymi klinicznymi i wsparciem społecznym, a także liczbą barier w dostępie do leczenia odwykowego.

\section{- Materiat I metody}

Badania przeprowadzono w grupie 89 mężczyzn spełniających kryteria uzależnienia od alkoholu według ICD-10, których podzielono na dwie podgrupy [18]. Pierwsza była złożona z 60 mężczyzn leczonych stacjonarnie odwykowo (średnia wieku 43 lata, $\mathrm{SD}=10$ ). Druga obejmowała 29 bezdomnych mężczyzn (średnia wieku 45 lat, $\mathrm{SD}=12$ ) z dwóch placówek - centrum pomocy dla osób bezdomnych i hostelu.

$\mathrm{Z}$ osobami $\mathrm{z}$ obu podgrup przeprowadzono wywiad, który zawierał m.in. pytania dotyczące danych społeczno-demograficznych (wiek, stan cywilny, wykształcenie i źródło utrzymania, liczba źródeł wsparcia społecznego, np. ze strony rodziny czy pomocy społecznej), zmiennych klinicznych dotyczących uzależnienia od alkoholu (czas trwania i głębokość uzależnienia, liczba dni picia, liczba spożytych drinków standardowych w miesiącu w okresie ostatnich 6 miesięcy), liczby zaburzeń somatycznych (takich jak nadciśnienie tętnicze, urazy, zaburzenia w funkcjonowaniu wątroby, endokrynologiczne, kardiologiczne, dermatologiczne, neurologiczne, dysfunkcje układu pokarmowego i oddechowego, naczyniowe, tarczycowe, onkologiczne), a także liczby zaburzeń psychicznych (lęku, braku energii do działania, smutku, agresji, bezsenności, natręctw, majaczenia drżennego, omamów). Kwestionariusz dawał możliwość wyboru wielu odpowiedzi w zakresie dolegliwości somatycznych i psychicznych.

Do oceny psychometrycznej zastosowano wymienione niżej narzędzia.

- Skalę SF-36 (Medical Outcomes Study - MOS, Short Form 36-item) autorstwa Ware i wsp. do subiektywnej oceny stanu zdrowia $\mathrm{w}$ ostatnim miesiącu przed badaniem, zaadaptowaną do warunków polskich przez Żołnierczyk-Zredę i wsp. Jest to jedno z powszechniej używanych narzędzi badania jakości życia uwarunkowanej stanem 
ing to eight categories like $\mathrm{F}$ - physical functioning: health problems limiting physical capacity e.g. carrying shopping, climbing stairs; $\mathrm{R}$ - role limitations due to physical problems: limitation of activity due to physical health; $\mathrm{P}$ - bodily pain: presence of physical pain, its intensity and effect on functioning; $\mathrm{H}$ - general health perception; $\mathrm{V}$ - vitality; $\mathrm{S}$ - social functioning and the relation of state of health to interpersonal relations; $\mathrm{E}$ - role limitation due to emotional problems, which together with categories $\mathrm{R}$ and $\mathrm{P}$ measures the limitation of everyday functioning; $\mathrm{W}$ - general mental health, psychological distress and psychological well-being: this subscale informs of mood disorders and anxieties. Additionally the subject assesses his state of health in the last year. The result of each category may be presented in percentages and fitted in the range of 0 to 100 or in the form of normalised results where 50 means the average value in each of the measured categories. One can definitively present a summary of the quality of life in two components (summary or general indicators) the Physical Component Summary (PCS) and the Mental Component Summary (MCS). The higher the score reported, the higher the quality of life level. The SF-36 questionnaire is usually used with people displaying a wide range of health issues due to the general character of the questions [19]. The described scale received positive opinion in terms of reliability and psychometric value [10, 20-22]. In order to carry out studies using this scale, we gained Quality Metric Incorporated license no. F1-112607-33684, while we also took advantage of Żołnierczyk-Zreda's et al. study, authors of Polish adaptation [23].

- The Beck Depression Inventory (BDI) to measure the intensity of depression symptoms in the month prior to the study in the Polish adaptation by Parnowski and Jernajczyk. The inventory contains 21 areas (including assessment of one's own situation, mood, motivation to act and suicidal thoughts) with answers on a scale of $0-3$. The final result is gained by summing the scores, with the higher the number the greater the intensity of depression symptoms. A score of 13 points or more for alcohol dependent persons may suggest the diagnosis of depression $[24,25]$. zdrowia. Skalę tworzy 36 pytań z ośmiu kategorii: F (funkcjonowanie fizyczne; physical functioning) - problemy zdrowia ograniczające sprawność fizyczną, np. noszenie zakupów, wchodzenie po schodach; R (ograniczenia roli, problemy fizyczne; role limitations due to physical problems) - ograniczenie aktywności z powodu zdrowia fizycznego; P (ból; bodily pain) - obecność bólu somatycznego, jego nasilenie oraz wpływ na funkcjonowanie; H (zdrowie ogólne; general health perception) ogólna ocena zdrowia; V (witalność; vitality) energia/witalność; S (funkcjonowanie społeczne; social functioning) - zależność relacji interpersonalnych od stanu zdrowia; E (ograniczenia roli, problemy emocjonalne; role limitation due to emotional problems) - ograniczenia w funkcjonowaniu z przyczyn emocjonalnych, która łącznie $\mathrm{z}$ kategorią $\mathrm{R}$ i $\mathrm{P}$ mierzy ograniczenia codziennych czynności; W (zdrowie psychiczne; general mental health, psychological distress and psychological well-being) - obecność zaburzeń nastroju, obaw czy lęków. Dodatkowo badany ocenia swój stan zdrowia w ostatnim roku. Wynik z każdej kategorii może być przedstawiony $\mathrm{w}$ formie procentowej i mieścić się $\mathrm{w}$ przedziale od 0 do 100 lub w formie wyników znormalizowanych, gdzie 50 w każdej mierzonej kategorii oznacza wartość przeciętną. W ostatecznym podsumowaniu jakość życia można przedstawić w formie dwóch składowych (wskaźników sumarycznych, ogólnych): składowej podsumowującej funkcjonowanie fizyczne (Fiz) oraz funkcjonowanie psychiczne (Psy). Im wyższy wynik, tym wyższy poziom jakości życia. Kwestionariusz SF-36 ze względu na ogólny charakter pytań jest często stosowany wśród osób z różnymi zaburzeniami zdrowotnymi [19]. Opisywana skala otrzymała pozytywne opinie pod względem wartości psychometrycznych i wiarygodności [10, 20-22]. Aby przeprowadzić badania z użyciem tej skali, uzyskano z Quality Metric Incorporated licencję nr F1-112607-33684, a także skorzystano z badań Żołnierczyk-Zredy i wsp., autorów polskiej adaptacji [23].

- Inwentarz Depresji Becka (Beck Depression Inventory - BDI) do oceny nasilenia objawów depresyjnych $\mathrm{w}$ ostatnim miesiącu przed badaniem, w polskiej adaptacji Parnowskiego i Jernajczyka. Zawiera 21 obszarów (m.in. ocena własnej sytuacji, nastrój, motywacja do działania, myśli samobójcze). Odpowiedzi udziela się na skali $0-3$. Ostateczny wynik uzyskuje się poprzez zsumowanie punktacji. Im jest on wyższy, tym większe 
- The Mini-Mental State Examination (MMSE) by Folstein et al. to assess the cognitive capacity of the study subjects including direct memory, attention, orientation in time and place, writing, naming, reading, following complex instructions and constructive praxis. MMSE consists of 10 questions allowing assessment of the above areas. The highest gained score is 30 points, which indicates a lack of cognitive deficits. The majority of scientific work suggests that a result of 24 points or less may indicate signs of dementia in the subject. It is however suggested that among persons of higher education level, a result of 27 points, and one of $22 / 23$ points for the less well educated, is a basis for further dementia diagnosis (the MMSE diagnostic scale concerns core dementia) [26, 27].

- Spielberger's State-Trait Anxiety Inventory (STAI) to assess the intensity of anxiety symptoms adapted to Polish conditions by Strelau et al. The instrument consists of two parts forming 20 questions rating anxiety as a personality trait (understood as an acquired and relatively stable disposition to anxiety reactions in objectively non-threatening situations) and 20 questions diagnosing anxiety as a state; that is the respondent's state of being at the time of study. Each question is answered on a four-point scale. The final result is gained by summing the points the total of which, in accordance to the answer key, is proportional to the intensity of anxiety symptoms. Normalisation of the test for a group of alcohol dependent men in rehab in-patient treatment was conducted by Lipczyński [28]. In accordance with the normalisation study and the standard-ten scale, the average STAI scale result (anxiety as a trait) was between 42 and 51 points [29].

- Short Alcohol Dependence Data Questionnaire (SADD) analyses the depth of alcohol dependency with 15 questions concerning the alcohol drinking situation, state of being and selfassessment of alcohol behaviour. Each question is on a 0-3 scale. SADD provides the possibility of a three-step division in the intensity of alcohol dependency as 1-9 points indicates mild, 10-19 moderate and 20-45 points deep dependency ( 0 is a lack of dependency). The scale was adapted to Polish conditions by Ziółkowski $[30,31]$. nasilenie objawów depresyjnych. U osób z uzależnieniem od alkoholu wynik 13 punktów i więcej może sugerować rozpoznanie depresji [24, 25].

- Skalę Mini-Mental State Examination (MMSE) Folsteina i wsp. do oceny sprawności poznawczej osób badanych, tj. pamięci bezpośredniej, uwagi, orientacji w czasie i miejscu, pisania, nazywania, czytania, wykonywania złożonych poleceń i praksji konstrukcyjnej. MMSE składa się 10 pytań, które umożliwiają ocenę powyższych obszarów. Najwyższy uzyskany wynik to 30 punktów, co wskazuje na brak deficytów poznawczych. Większość prac naukowych podaje, że wynik 24 punkty i mniej może wskazywać na cechy otępienne u osoby badanej. Sugeruje się jednak, by u osób z wyższym poziomem wykształcenia wynik 27 punktów, a u osób z niższym wykształceniem wynik 22 lub 23 punkty był podstawą do dalszej diagnostyki zaburzeń otępiennych (diagnostyka skalą MMSE dotyczy otępień korowych) [26, 27].

- Inwentarz Stanu i Cech Lęku (State-Trait Anxiety Inventory - STAI) Spielbergera do oceny nasilenia objawów lękowych, w polskiej adaptacji Strelaua i wsp. Składa się z dwóch części, które tworzy 20 pytań oceniających lęk jako cechę osobowości (rozumianą jako nabytą i relatywnie stałą dyspozycję do reakcji lękowych w obiektywnie niegroźnych sytuacjach) oraz 20 pytań diagnozujących lęk jako stan, czyli samopoczucie respondentów w chwili badania. Na każde z pytań respondent udziela odpowiedzi na 4-stopniowej skali. Ostateczny wynik uzyskuje się poprzez przeliczenie punktacji. Zgodnie z kluczem odpowiedzi jest on proporcjonalny do nasilenia objawów lękowych. Normalizację testu w Polsce w grupie mężczyzn uzależnionych od alkoholu, leczonych stacjonarnie odwykowo przeprowadził Lipczyński [28]. Zgodnie $\mathrm{z}$ badaniami normalizacyjnymi według skali stenowej przeciętny wynik skali STAI (lęk jako cecha) wynosi między 42 a 51 punktów [29].

- Skalę SADD (Short Alcohol Dependence Data Questionnaire) do analizy głębokości uzależnienia od alkoholu. Zawiera 15 pytań dotyczących sytuacji picia alkoholu, samopoczucia i samooceny zachowań alkoholowych. Każde z pytań opatrzone jest skalą $0-3$. Kwestionariusz daje możliwość trzystopniowego podziału nasileniauzależnienia od alkoholu-napoziomie 1-9 punktów oznacza uzależnienie łagodne, 10-19 umiarkowane, 20-45 głębokie (0 - brak uzależnienia). Do polskich warunków skalę zaadaptował Ziółkowski [30, 31]. 
The statistics programme SPSS 22.0 was applied to assess the results with a level of statistical significance set at $p \leq 0.05$.

\section{- Results}

At the beginning we presented the socio-demographic data and number of social support sources for the studied men in Table I. Both of the study groups were of similar age though they differed
Do oceny wyników badań zastosowano program statystyczny SPSS 22.0. Za poziom istotności statystycznej przyjęto $p \leq 0,05$.

\section{- WYNIKI}

$\mathrm{Na}$ wstępie w tabeli I zaprezentowano dane społeczno-demograficzne i liczbę źródeł wsparcia społecznego badanych mężczyzn. Jak widać, obie badane grupy były w podobnym wieku, natomiast

Table I. Socio-demographic variables and number of social support sources concerning alcohol dependent persons: the rehab inpatients and shelter or hostel homeless

Tabela I. Zmienne społeczno-demograficzne i liczba źródeł wsparcia społecznego u osób uzależnionych od alkoholu pacjentów leczonych stacjonarnie odwykowo oraz bezdomnych przebywających w schronisku lub hostelu

\begin{tabular}{|c|c|c|}
\hline \multirow[t]{2}{*}{ Variables/Zmienne } & $\begin{array}{c}\text { Rehab inpatients/ } \\
\text { Pacjenci leczeni stacjonarnie } \\
\text { odwykowo } \\
n=60\end{array}$ & $\begin{array}{c}\text { Shelter or hostel homeless/ } \\
\text { Osoby bezdomne ze schroniska } \\
\text { lub hostelu } \\
n=29\end{array}$ \\
\hline & \multicolumn{2}{|c|}{$\mathrm{x} \pm \mathrm{SD}$ (range) or number $(\%) / \mathrm{x} \pm \mathrm{SD}$ i liczba (\%) } \\
\hline Age (years)/Wiek (lata) & $43 \pm 10(22-63)$ & $45 \pm 12(22-68)$ \\
\hline \multicolumn{3}{|l|}{ Marital status/Stan cywilny } \\
\hline Married/W związku & $36(60.0 \%)$ & $4(13.8 \%)^{\star}$ \\
\hline Widow/Wdowiec & $1(1.7 \%)$ & $0(0.0 \%)$ \\
\hline Separated/W separacji & $1(1.7 \%)$ & $2(6.9 \%)$ \\
\hline Divorced/Rozwiedziony & $13(21.7 \%)$ & $11(37.9 \%)$ \\
\hline Concubinage/W konkubinacie & $2(3.2 \%)$ & $1(3.5 \%)$ \\
\hline Single/Samotny & $7(11.7 \%)$ & $11(37.9 \%)^{*}$ \\
\hline \multicolumn{3}{|l|}{ Education/Wykształcenie } \\
\hline Basic school/Podstawowe & $3(5.0 \%)$ & $10(34.5 \%)^{*}$ \\
\hline Vocational school/Zawodowe & $30(50.0 \%)$ & $11(37.9 \%)$ \\
\hline High school/Średnie & $19(31.7)$ & $7(24.1 \%)$ \\
\hline College/Wyższe & $8(13.3 \%)$ & $1(3.5 \%)$ \\
\hline \multicolumn{3}{|l|}{ Employment/Źródło dochodu } \\
\hline Unemployed/Bezrobotny & $13(21.7 \%)$ & $12(41.4 \%)$ \\
\hline $\begin{array}{l}\text { Pension (retirement or handicap)/ } \\
\text { Renta lub emerytura }\end{array}$ & $10(16.7 \%)$ & $4(13.8 \%)$ \\
\hline Work/Praca & $37(61.6)$ & $12(41.3)$ \\
\hline Dole/Zasiłek & $0(0.0 \%)$ & $1(3.5 \%)$ \\
\hline $\begin{array}{l}\text { Number of sources of social support/ } \\
\text { Liczba źródeł wsparcia społecznego }\end{array}$ & $2.00 \pm 0.95(0-4)$ & $1.45 \pm 1.21(0-4)^{\#}$ \\
\hline
\end{tabular}

Fisher's exact test, where ${ }^{*} p \leq 0.01 ; \cup$ Mann-Whitney test, where ${ }^{*} p \leq 0.05 /$ Test dokładny Fishera, gdzie * $p \leq 0,01$; test U Manna-Whitneya, gdzie ${ }^{*} p \leq 0,05$ 
Table II. Clinical variables and psychometric data concerning alcohol dependent persons: the rehab inpatients and shelter or hostel homeless

Tabela II. Dane kliniczne i psychometryczne osób uzależnionych od alkoholu - pacjentów leczonych stacjonarnie odwykowo oraz bezdomnych przebywających w schronisku lub hostelu

\begin{tabular}{|c|c|c|c|}
\hline \multirow[t]{2}{*}{ Variables/Zmienne } & $\begin{array}{l}\text { Rehab inpatients/ } \\
\text { Pacjenci leczeni } \\
\text { stacjonarnie } \\
\text { odwykowo } \\
n=57-60\end{array}$ & $\begin{array}{c}\text { Shelter or hostel } \\
\text { homeless/Osoby } \\
\text { bezdomne ze } \\
\text { schroniska lub hostelu } \\
n=21-29\end{array}$ & \multirow[t]{2}{*}{$p$} \\
\hline & \multicolumn{2}{|c|}{$x \pm S D$} & \\
\hline $\begin{array}{l}\text { Number of days of alcohol drinking in the month } \\
\text { at the last time of drinking/Liczba dni picia alkoholu } \\
\text { w miesiącu w ostatnim okresie picia alkoholu }\end{array}$ & $19.22 \pm 9.80$ & $22.62 \pm 9.21$ & 0.10 \\
\hline $\begin{array}{l}\text { Number of standard drinks in the month at the last } \\
\text { time of drinking/Liczba drinków standardowych } \\
\text { wypitych w miesiącu w ostatnim okresie picia alkoholu }\end{array}$ & $323.36 \pm 315.54$ & $634.51 \pm 500.23$ & 0.01 \\
\hline $\begin{array}{l}\text { Duration of alcohol dependence (years)/ } \\
\text { Czas trwania uzależnienia od alkoholu (w latach) }\end{array}$ & $13.15 \pm 9.10$ & $17.19 \pm 8.61$ & $0.056^{a}$ \\
\hline $\begin{array}{l}\text { Number of somatic problems/ } \\
\text { Liczba problemów somatycznych }\end{array}$ & $0.57 \pm 0.83$ & $1.07 \pm 1.60$ & $0.08^{a}$ \\
\hline $\begin{array}{l}\text { Number of mental symptoms/ } \\
\text { Liczba problemów psychicznych }\end{array}$ & $2.03 \pm 1.40$ & $2.0 \pm 2.05$ & 0.30 \\
\hline $\begin{array}{l}\text { Number of medical interventions/ } \\
\text { Liczba interwencji medycznych }\end{array}$ & $1.47 \pm 0.92$ & $2.17 \pm 1.49$ & 0.01 \\
\hline SADD (scoring)/SADD (punktacja) & $21.23 \pm 7.20$ & $25.13 \pm 11.35$ & 0.02 \\
\hline MMSE (scoring)/MMSE (punktacja) & $28.43 \pm 1.61$ & $26.64 \pm 2.72$ & 0.001 \\
\hline BDI (scoring)/BDI (punktacja) & $16.77 \pm 8.51$ & $12.31 \pm 9.48$ & 0.02 \\
\hline $\begin{array}{l}\text { STAI - anxiety as a trait (scoring)/ } \\
\text { STAI - lęk jako cecha (punktacja) }\end{array}$ & $43.75 \pm 10.30$ & $40.83 \pm 10.72$ & 0.24 \\
\hline
\end{tabular}

U Mann-Whitney test $p<0.05$; ${ }^{a}$ trend toward statistical significance/Test U Manna-Whitneya $p<0,05$; atrend ku znamienności statystycznej

in terms of a number of demographic variables. Homeless persons were significantly rarely in a partnership and were less well educated than rehab inpatients.

A further assessment concerned respondents' clinical data and their results on the psychometric scales (Table II). In order to compare the study subjects in two groups, we applied the Mann-Whitney $U$ test and the $\chi^{2}$ test. As Table II shows, homeless persons consumed significantly more alcohol in the last month of drinking, were more deeply dependent (higher SADD score) and in the past needed more frequent medical intervention and experienced more serious cognitive deficits of direct memory, attention, orientation in time and place, writing, naming of objects, reading, following complex instructions and constructive praxis (MMSE scale) than rehab inpatients. The lat- różniły się kilkoma zmiennymi demograficznymi. Osoby bezdomne znacząco rzadziej żyły w związku partnerskim oraz były gorzej wykształcone niż osoby leczone stacjonarnie odwykowo.

Kolejna ocena dotyczyła danych klinicznych respondentów i wyników uzyskanych przez nich w skalach psychometrycznych (tab. II). Do porównania badanych $w$ podgrupach użyto testu $U$ Manna-Whitneya oraz testu $\chi^{2}$. Jak pokazuje tabela II, osoby bezdomne spożywały istotnie statystycznie więcej alkoholu w czasie ostatniego miesiąca w okresie, w którym piły alkohol, były bardziej uzależnione (wyższa punktacja w skali SADD), w przeszłości wymagały liczniejszych interwencji medycznych i doświadczały poważniejszych deficytów poznawczych w obszarze: pamięci bezpośredniej, uwagi, orientacji w czasie i miejscu, pisania, nazywania przedmiotów, czytania, wykonywania złożonych poleceń i praksji 
Table III. The normalised outcomes of subscales SF-36 for the two groups Tabela III. Znormalizowane wyniki podskal SF-36 w dwóch badanych podgrupach

\begin{tabular}{|c|c|c|c|}
\hline \multirow[t]{2}{*}{ Variables/Zmienne } & $\begin{array}{l}\text { Rehab inpatients/ } \\
\text { Pacjenci leczeni } \\
\text { stacjonarnie } \\
\text { odwykowo } \\
n=60\end{array}$ & $\begin{array}{l}\text { Shelter or hostel } \\
\text { homeless/Osoby } \\
\text { bezdomne ze } \\
\text { schroniska lub hostelu } \\
n=29\end{array}$ & \multirow[t]{2}{*}{$p$} \\
\hline & \multicolumn{2}{|c|}{$x \pm S D$} & \\
\hline F - physical functioning/F - funkcjonowanie fizyczne & $51.31 \pm 6.97$ & $49.34 \pm 6.94$ & 0.11 \\
\hline $\begin{array}{l}R \text { - role limitations due to physical problems/ } \\
R \text { - ograniczenia roli w wyniku problemów fizycznych }\end{array}$ & $46.16 \pm 9.59$ & $46.81 \pm 9.19$ & 0.78 \\
\hline$P$ - bodily pain/P - ból & $48.43 \pm 11.38$ & $45.49 \pm 12.12$ & 0.29 \\
\hline $\mathrm{H}$ - general health perception/H - zdrowie ogólne & $44.21 \pm 9.30$ & $41.62 \pm 8.34$ & 0.19 \\
\hline V - vitality/V - witalność & $48.14 \pm 11.27$ & $49.30 \pm 10.16$ & 0.58 \\
\hline S - social functioning/S - funkcjonowanie społeczne & $40.94 \pm 11.67$ & $43.68 \pm 11.15$ & 0.24 \\
\hline $\begin{array}{l}\text { E - role limitation due to emotional problems/ } \\
\text { E - ograniczenia roli w wyniku problemów emocjonalnych }\end{array}$ & $41.68 \pm 11.33$ & $46.09 \pm 11.50$ & $0.06^{\mathrm{a}}$ \\
\hline W - general mental health/W - zdrowie psychiczne & $39.07 \pm 11.81$ & $42.23 \pm 12.38$ & 0.25 \\
\hline $\begin{array}{l}\text { PCS - physical component summary/Fiz - zdrowie } \\
\text { fizyczne, podsumowanie }\end{array}$ & $50.81 \pm 8.53$ & $47.38 \pm 9.06$ & 0.10 \\
\hline $\begin{array}{l}\text { MCS - mental component summary/Psy - zdrowie } \\
\text { psychiczne, podsumowanie }\end{array}$ & $38.62 \pm 12.46$ & $43.78 \pm 12.16$ & $0.06^{\mathrm{a}}$ \\
\hline
\end{tabular}

U Mann-Whitney test $p<0.05 ;{ }^{a}$ trend toward statistical significance/Test U Manna-Whitneya $p<0,05 ;{ }^{a}$ trend ku znamienności statystycznej

ter however differed from the homeless in terms of higher intensity of depression symptoms (BDI scale).

The data gained from comparison quality of life of rehab inpatients and the homeless is presented in Table III. We used Mann-Whitney's $U$ test for this purpose. Table III shows a similar point system to most SF-36 subscales (8 out of 10 subscales) for respondents of both groups. The homeless gained results at a lower level than average on all subscales (the average result equals 50 with a $S D=10)$ like the rehab inpatients. The exception was two subscales - F (physical functioning) and PCS (physical component summary), which showed equally average or higher scores. Rehab inpatients scored a lower point average (at the statistical tendency level) than the homeless in subscales E (emotionally motivated role limitation) and MCS (mental component summary).

In order to precisely describe the relations between the general SF-36 scales (concerning physical and mental health) and selected variables: e.g. the number of social support sources, time konstrukcyjnej (skala MMSE) niż pacjenci z oddziału odwykowego. Ci ostatni natomiast różnili się od osób bezdomnych wyższym nasileniem objawów depresyjnych (skala BDI).

W tabeli III przedstawiono dane dotyczące jakości życia osób leczonych stacjonarnie odwykowo i bezdomnych. W celu porównania użyto testu U Manna-Whitneya. Tabela III pokazuje podobną punktację w większości podskal SF-36 (w 8 na 10 podskal) u respondentów $\mathrm{z}$ obu podgrup. Osoby bezdomne we wszystkich podskalach uzyskały wyniki na poziomie niższym niż przeciętna (wynik przeciętny równa się tu 50, przy $\mathrm{SD}=10$ ), podobnie jak pacjenci leczeni stacjonarnie. Wyjątek stanowią dwie podskale: F (funkcjonowanie fizyczne) i Fiz (podsumowująca zdrowie fizyczne), których punktacje były równe przeciętnej lub wyższe. Pacjenci leczeni stacjonarnie uzyskali niższą średnią punktację (na poziomie tendencji statystycznej) niż osoby bezdomne w podskalach E (ograniczenie roli na tle emocjonalnym) oraz Psy (ogólna ocena zdrowia psychicznego).

Aby dokładnie opisać relacje między ogólnymi skalami SF-36 (dotyczącymi zdrowia fizycznego 
Table IV. The general subscales SF-36 results achieved by respondents from the two groups related to selected clinical variables and social support - the multiple regression backward elimination method

Tabela IV. Wyniki uzyskane przez respondentów z obu podgrup w podskalach ogólnych SF-36 a wybrane zmienne kliniczne i wsparcie społeczne - regresja wielokrotna metodą eliminacji wstecznej

\begin{tabular}{|c|c|c|c|c|c|c|c|c|}
\hline \multirow{3}{*}{$\begin{array}{l}\text { Component } \\
\text { summary SF-36/ } \\
\text { Podskale podsu- } \\
\text { mowujące SF-36 }\end{array}$} & \multicolumn{4}{|c|}{$\begin{array}{c}\text { Rehab inpatients/Pacjenci leczeni stacjonarnie } \\
\text { odwykowo, } n=53\end{array}$} & \multicolumn{4}{|c|}{$\begin{array}{l}\text { Shelter or hostel homeless/Osoby bezdomne } \\
\text { ze schroniska lub hostelu, } n=21\end{array}$} \\
\hline & \multirow[t]{2}{*}{$\begin{array}{l}\text { Variables/ } \\
\text { Zmienne }\end{array}$} & $\begin{array}{c}\text { Standardised } \\
\text { coefficients/ } \\
\text { Współczynniki } \\
\text { standaryzowane }\end{array}$ & \multirow[t]{2}{*}{$p$} & \multirow[t]{2}{*}{$R^{2}$} & \multirow[t]{2}{*}{$\begin{array}{l}\text { Variables/ } \\
\text { Zmienne }\end{array}$} & $\begin{array}{c}\text { Standardised } \\
\text { coefficients/ } \\
\text { Współczynniki } \\
\text { standaryzowane }\end{array}$ & \multirow[t]{2}{*}{$p$} & \multirow[t]{2}{*}{$R^{2}$} \\
\hline & & Beta & & & & Beta & & \\
\hline \multirow[t]{3}{*}{ PCS/Fiz } & $\begin{array}{l}\text { Number } \\
\text { of somatic } \\
\text { problems/ } \\
\text { Liczba } \\
\text { problemów } \\
\text { somatycznych }\end{array}$ & -0.348 & 0.006 & \multirow{3}{*}{0.256} & $\begin{array}{l}\text { Number of days } \\
\text { drinking/Liczba } \\
\text { dni picia }\end{array}$ & -0.992 & 0.002 & \multirow{3}{*}{0.513} \\
\hline & $\begin{array}{l}\text { STAI (anxiety } \\
\text { as a trait)/ } \\
\text { STAI (lęk jako } \\
\text { cecha) }\end{array}$ & -0.345 & 0.007 & & $\begin{array}{c}\text { Number } \\
\text { of drinks/ } \\
\text { Liczba drinków }\end{array}$ & 0.935 & 0.003 & \\
\hline & & & & & $\begin{array}{c}\text { Duration } \\
\text { of alcohol } \\
\text { dependence/Czas } \\
\text { uzależnienia }\end{array}$ & -0.457 & 0.018 & \\
\hline \multirow[t]{4}{*}{ MCS/Psy } & BDI & -0.324 & 0.019 & \multirow{4}{*}{0.612} & BDI & -0.653 & 0.0005 & \multirow{4}{*}{0.848} \\
\hline & $\begin{array}{l}\text { STAI (anxiety } \\
\text { as a trait)/ } \\
\text { STAI (lęk jako } \\
\text { cecha) }\end{array}$ & -0.283 & 0.031 & & $\begin{array}{c}\text { Number of } \\
\text { sources of social } \\
\text { support/Liczba } \\
\text { źródeł wsparcia }\end{array}$ & -0.329 & 0.010 & \\
\hline & $\begin{array}{l}\text { Number } \\
\text { of mental } \\
\text { symptoms/ } \\
\text { Liczba } \\
\text { problemów } \\
\text { psychicznych }\end{array}$ & -0.220 & 0.048 & & $\begin{array}{c}\text { Number } \\
\text { of mental } \\
\text { symptoms/Liczba } \\
\text { problemów } \\
\text { psychicznych }\end{array}$ & -0.328 & 0.027 & \\
\hline & MMSE & -0.170 & 0.085 & & $\begin{array}{l}\text { Number of } \\
\text { drinks/Liczba } \\
\text { drinków }\end{array}$ & 0.206 & 0.095 & \\
\hline
\end{tabular}

in dependency, the number of days drinking in the unit of time, the number of standard drinks in the set time, number of physical disorders and psychopathological symptoms and STAI (anxiety as a trait), BDI, SADD, MMSE scales, we applied multiple regression (backward elimination method in which the result was included with $p$ at a minimum value of 0.05 and excluded at a $p$ greater than 0.1 ). Table IV presents the results. The largest explained variation result percent- i psychicznego) a wybranymi zmiennymi, tj. liczbą źródeł wsparcia społecznego, czasem trwania uzależnienia, liczbą dni picia alkoholu w jednostce czasu, liczbą spożytych drinków standardowych w określonym czasie, liczbą zaburzeń somatycznych i objawów psychopatologicznych oraz wynikami skal STAI (lęk jako cecha), BDI, SADD, MMSE, zastosowano regresję wielokrotną (metoda eliminacji wstecznej, gdzie wynik włączano przy $p$ o wartości minimum 0,05 , a wykluczano przy $p>0,1$ ). Wyniki 
age of rehab inpatients was that which showed a negative relation of general subscales for quality of mental functioning (MCS) with the results of BDI and STAI scales and the number of mental symptoms. Among the homeless, the largest percentage of variation was also explained in relation to mental functioning where a significant role for the level of depression, number of mental symptoms and also of number of sources of support was revealed, which was not noted in the inpatient group. Differing predictors were also gained for the general assessment of physical functioning quality (PCS), and in the case of inpatients this was the number of physical illnesses and the level of anxiety as a trait, while among the homeless the variables concerned alcohol dependency (number of drinks and time in dependency).

\section{- Discussion of RESUlts}

Alcohol abuse leads to numerous health issues and social and economic problems that to a greater or lesser extent limit the functioning of the individual [16]. On the one hand it generates the search for specialist help (e.g. medical care), and on the other it may pose a direct or indirect obstacle to the undertaking of treatment. According to studies by Schanzer et al. [16], the homeless very often resort to medical care in emergency wards $[8,16]$, which may indicate the sudden course of hitherto untreated illnesses or the injuries.

Comparison of rehab inpatients (with a lower intensity of dependency, consuming a smaller amount of alcohol in the last drinking period, more cognitively effective but with more intense depression symptoms) with shelter homeless, who were more likely to be single, less well-educated and were more likely to undergo treatment for health reasons, did not reveal differences in functioning in the majority of life areas in accordance with the SF-36 scale measuring the quality of life linked to state of health.

Literature data indicates that homelessness implies the large burden of mental and physical problems, also increasing therapeutic problems like long-term hospitalisation and frequent relapses of physical and mental disorders or their chronic course (which doubtlessly lowers the quality of life) and also increases the likelihood of fatality [16]. przedstawiono $\mathrm{w}$ tabeli IV. U pacjentów oddziału odwykowego najwyższy procent tłumaczonej wariancji wyników to ten, w którym wykazano ujemne relacje podskali ogólnej oceny jakości funkcjonowania psychicznego (Psy) z wynikami skali BDI, STAI oraz liczbą objawów psychicznych. U bezdomnych największy procent wariancji był również wyjaśniany $\mathrm{w}$ odniesieniu do funkcjonowania psychicznego, gdzie wykazano istotną rolę poziomu depresji, liczby objawów psychicznych, a także liczby źródeł wsparcia, czego nie stwierdzono w grupie pacjentów hospitalizowanych. Odmienne predyktory otrzymano także dla ogólnej oceny jakości funkcjonowania fizycznego (Fiz) - w przypadku pacjentów leczonych stacjonarnie były to liczba schorzeń somatycznych oraz poziom lęku jako cechy, podczas gdy u bezdomnych zmienne dotyczące uzależnienia od alkoholu (liczba drinków, czas trwania uzależnienia).

\section{- OmóWIENIE WYNIKóW}

Nadużywanie alkoholu prowadzi do licznych szkód zdrowotnych, społecznych, ekonomicznych, co w różnym stopniu ogranicza funkcjonowanie jednostki [16]. Z jednej strony generuje poszukiwanie pomocy specjalistycznej, np. medycznej i odwykowej, z drugiej może stanowić bezpośrednią lub pośrednią przeszkodę w podjęciu leczenia. Według Schanzer i wsp. [16] bezdomni bardzo często korzystają z opieki medycznej na oddziałach ratunkowych $[8,16]$, co może świadczyć o nagłym przebiegu schorzeń, których właściwie dotąd nie leczono, bądź o urazach.

Porównanie pacjentów leczonych stacjonarnie odwykowo (o mniejszym natężeniu uzależnienia, spożywających mniejsze ilości alkoholu w ostatnim okresie picia, sprawniejszych poznawczo, ale z bardziej nasilonymi objawami depresyjnymi) z osobami bezdomnymi - „schroniskowymi”, które częściej żyły w stanie wolnym, były gorzej wykształcone i częściej podejmowały leczenie z powodów somatycznych, nie wykazało różnic w funkcjonowaniu w większości obszarów życia według skali SF-36 badającej jakość życia w powiązaniu ze stanem zdrowia.

Według danych $z$ literatury bezdomność niesie ze sobą duże obciążenie problemami psychicznymi i fizycznymi, zwiększając również problemy terapeutyczne, takie jak długo trwające hospitalizacje, częste nawroty zaburzeń somatycznych i psychicznych czy ich przewlekły przebieg (bezspornie obniżając jakość życia), a także prawdopodobieństwo zgonu [16]. 
The result of Schanzer's et al. study is close to that gained in this research, which detected a lack of difference in the assessed areas of life quality (SF-36) between the homeless starting their shelter stay and those who had been there for a year and a half. The authors propose the thesis that this result probably depends on other factors than those included in the SF-36 scale [16].

We observed slightly worse mental functioning and a related slight limitation of fulfilment of daily tasks for emotional reasons among the rehab inpatients than the homeless. This may be due to the shorter period of abstinence among the inpatients than the homeless, who at the time of the study had been in the shelter or hostel for a number of weeks (which implied forced abstinence). This was also indicated by the greater burden of depression, in the form of a higher depression scale result, among the rehab inpatients compared to the homeless. This may have been influenced by the recent quitting of drinking (withdrawal syndrome), a greater insight into one's situation or a greater confrontation with the realities of life, e.g. lack of contact with close persons or loss of home or work, to which the homeless had been able to adapt. Interestingly, no differences in the intensity of anxiety symptoms between the two groups were detected.

It was revealed that both groups rated their physical functioning highly (physical functioning category and general assessment of physical health in the SF-36 questionnaire), similarly to respondents in French studies from 1998 [32].

We noted that persons dependent on alcohol, both rehab in-patients and homeless, rated their mental functioning especially low, which was also confirmed by Malet's et al. [33] and Chodkiewicz's studies [34].

This data are also confirmed by a research project rating the health requirements and quality of life (with the SF-36 scale) of the homeless in a shelter in Sheffield. This showed that respondents rated the level of health services as high but that of their health as lower in comparison to the general population. The majority (75\%) were threatened by depression. They also reported low results concerning social functioning, level of mental health, vitality and general parameters of health [35].

The authors of a study conducted in 1999 on a group of over 1300 basic health-care patients demonstrated that the worse functioning of the sub-
Wynik badań Schanzer i wsp. jest jednak zbliżony do uzyskanego w niniejszej pracy - stwierdzono brak różnic w ocenianych obszarach jakości życia (SF-36) pomiędzy bezdomnymi zaczynającymi swój pobyt w schronisku a tymi, którzy przebywali w nim od półtora roku. Autorzy stawiają tezę, że taki wynik zależy prawdopodobnie od innych czynników niż te uwzględnione w skali SF-36 [16].

U pacjentów hospitalizowanych na oddziale odwykowym zaobserwowano nieznacznie gorsze niż u osób bezdomnych funkcjonowanie psychiczne i związane z tym nieznaczne ograniczenie pełnienia zadań życiowych z powodów emocjonalnych. Może to być wynikiem krótszego okresu abstynencji u pacjentów leczonych odwykowo niż u osób bezdomnych, które w chwili badania przebywały w schronisku lub hostelu już od kilku tygodni (co wiązało się z przymusową abstynencją). Przemawia za tym też większe obciążenie depresją (wyższy wynik w skali depresji) pacjentów oddziału odwykowego w porównaniu $\mathrm{z}$ bezdomnymi. Może mieć na to wpływ niedawne zaprzestanie picia alkoholu (zespół abstynencyjny), większy wgląd we własną sytuację czy większa konfrontacja z realiami życia, z którymi osoby bezdomne zdołały się pogodzić, np. rozłąka z najbliższymi, utrata mieszkania czy pracy. Co ciekawe, nie wykazano różnic w nasileniu objawów lękowych między obiema badanymi grupami.

Jak wykazano, obie grupy wysoko oceniały swoje funkcjonowanie fizyczne (kategoria funkcjonowanie fizyczne i ogólna ocena zdrowia fizycznego kwestionariusza SF-36), podobnie jak respondenci we francuskich badaniach przeprowadzonych w 1998 r. [32].

Stwierdzono, że osoby uzależnione od alkoholu zarówno leczone na oddziale odwykowym, jak i bezdomne - szczególnie nisko oceniły swoje funkcjonowanie psychiczne, co potwierdziły także badania Maleta i wsp. [33] i Chodkiewicza [34].

Dane te potwierdza również projekt badawczy, w którym oceniano potrzeby zdrowotne i jakość życia (z użyciem skali SF-36) bezdomnych z hostelu w Sheffield. $Z$ badań tych wiadomo, że respondenci ocenili poziom usług służby zdrowia jako wysoki, ale poziom swojego zdrowia jako niższy w porównaniu z populacją ogólną. Większość badanych (75\%) było zagrożonych depresją. Stwierdzono u nich też niskie wyniki dotyczące funkcjonowania społecznego, poziomu zdrowia psychicznego, witalności i ogólnych wymiarów zdrowia [35].

Autorzy badań przeprowadzonych w 1999 r. w grupie ponad 1300 pacjentów z podstawowej opie- 
jects in the mental sphere was linked to alcohol abuse since it causes, among others, depressive disorders and anxiety. Persons tended to drink more and more frequently, were clearly likely to function less well mentally and fulfilled their social roles more poorly [36, 37]. The suggestions of the French studies are similar as these noted that the low level of life quality (SF-36) of alcohol dependent patients is linked to a higher intensity of depression and deeper dependency $[32,38]$.

Multiple regression testing revealed that in rehab inpatients it was more intense anxiety disturbances (anxiety as a trait), and also more numerous experience of physical problems that lower the standard of life in the area of physical functioning $\left(R^{2}=0.25\right)$ while in the case of the homeless the assessment of the quality of life in this area is reduced mainly by behaviour linked to alcohol like the lengthened time of drinking and duration of alcohol dependency $\left(R^{2}=0.51\right)$. Similarly, the intensity of anxiety as a trait among rehab inpatients together with their experience of more serious depression symptoms and more numerous mental disorders influences towards a lowered assessment of mental quality of life $\left(R^{2}=0.61\right)$. Interpretation of regression testing results shows that the quality of mental life is badly rated by the homeless when (a result analogous to rehab inpatients) they report deeper and more numerous problems of a mental nature including symptoms of depression and also, which is specific to the group, if they gain greater (!) social support $\left(R^{2}=0.84\right)$.

The authors of foreign studies Kertesz et al. came to similar conclusions [39]. These interesting relations between the greater number of sources of social support and a lower assessment of mental life quality among the homeless may be explained as a lack of realisation of personal expectations that are "born" in confrontation with the social group.

As the work of Wenzel et al. shows, greater social support for persons dependent on psychoactive substances is linked to worse access to health problem treatment [8]. So having a supportive partner delays the decision to undertake treatment, which may lead to a deterioration in the state of health. On the other hand, studies by Warren et al. indicate that a significant predictor of success of undertaken therapy is personal resources like social support and the sense of one's own effectiveness [40]. The results described above suggest the need for further studies on the relation between "sup- ki zdrowotnej wykazali, że gorsze funkcjonowanie badanych w sferze psychicznej było związane z nadużywaniem alkoholu, skutkowało bowiem m.in. zaburzeniami depresyjnymi i lękowymi. Osoby, które upijały się, piły więcej i częściej wyraźnie gorzej funkcjonowały psychicznie i gorzej wypełniały swoje role społeczne [36, 37]. Podobne są sugestie francuskich badaczy, którzy zaobserwowali, że niski poziom jakości życia (skala SF-36) pacjentów uzależnionych od alkoholu jest związany z większym nasileniem depresji oraz głębszym uzależnieniem [32, 38].

Testowanie metodą regresji wielokrotnej wykazało, że u pacjentów leczonych stacjonarnie odwykowo to właśnie bardziej nasilone zaburzenia lękowe (lęk jako cecha), a także liczniej doświadczane problemy somatyczne obniżają poziom jakości życia w obszarze funkcjonowania fizycznego $\left(R^{2}=0,25\right)$; w przypadku osób bezdomnych ocenę jakości życia w tym obszarze obniżają z kolei głównie zachowania związane z alkoholem, tj. dłuższy czas picia i trwania uzależnienia od alkoholu $\left(R^{2}=0,51\right)$. Podobnie, nasilenie lęku jako cechy u pacjentów leczonych stacjonarnie odwykowo wraz z doświadczaniem przez nich poważniejszych objawów depresyjnych oraz liczniejszych zaburzeń psychicznych wpływa na obniżenie oceny jakości życia psychicznego $\left(R^{2}=0,61\right)$. Interpretacja wyników testu regresji pokazała, że jakość życia psychicznego jest źle oceniana przez osoby bezdomne, gdy (wynik analogiczny jak u pacjentów oddziału odwykowego) zgłaszają głębsze i liczniejsze problemy natury psychicznej, w tym objawy depresyjne, a także (co jest dla tej grupy specyficzne) jeśli korzystają z większego (!) wsparcia społecznego $\left(R^{2}=0,84\right)$.

Do podobnych wniosków doszli autorzy badań zagranicznych Kertesz i wsp. [39]. Tę ciekawą relację między większą liczbą źródeł wsparcia społecznego a niższą oceną poziomu jakości życia psychicznego u osób bezdomnych można tłumaczyć brakiem realizacji własnych oczekiwań, które „rodzą się" $\mathrm{w}$ konfrontacji z grupą społeczną.

Jak wynika z pracy Wenzel i wsp. większe wsparcie społeczne dla osoby uzależnionej od substancji psychoaktywnych wiąże się z gorszym dostępem do leczenia problemów zdrowotnych [8]. Posiadanie zatem wspierającego partnera odracza decyzję o podjęciu leczenia, co może prowadzić do pogorszenia stanu zdrowia. Z drugiej strony, badania Warren i wsp. wskazują, że istotnym predyktorem powodzenia podjętej terapii są zasoby osobiste, takie jak wsparcie społeczne i poczucie własnej skuteczności [40]. Opisane wyżej wyniki przemawiają za koniecznością 
port and the quality of life" among the homeless. For example, studies from 2015 revealed that an improvement in the quality of life of the homeless dependant on alcohol is connected to the health harm reduction [41].

There are other predictors of quality of life relating to physical health - among the homeless the level of life quality in this dimension is mainly determined by variables concerning alcohol dependency (number of drinks, days drinking and time in dependency) while for rehab inpatients, these variables turned out to be physical ailments and the level of anxiety.

The results of both parameters - physical and mental health indicate a more close relation between the quality of life and the picture of alcohol dependency among the homeless than the rehab inpatients. Namely et al. suggest that reduction of drinking contributes to the improvement in the quality of life of the homeless [41]. This means that activity designed to increase the quality of life in the homeless group ought to be directed mainly at the problems concerning dependency.

The gained results showed that the improvement in the quality of physical and mental functioning of alcohol dependent rehab inpatients may take place as a result of therapeutic activity including firstly diagnosis and reduction of depression and anxiety symptoms and secondly minimisation of physical disturbances immediately following the quitting of drinking [42]. Meanwhile, among the homeless an improvement in the same quality of life components could be gained through early interventions cutting down the drinking binges and optimisation of social support [41].

The presented research also has its limitations. Subjects were not asked how long they had been homeless, and the rating of the quality of life concerned the month prior to the study, which the subjects had spent in a hostel or shelter. Furthermore, the patients had spent at least three weeks at the rehab ward during the study, which could have influenced their rating of both their physical and mental health and the level of life quality. Another limitation was the number of subjects, especially the homeless. It would seem to be worthwhile to undertake further study on a larger group of "shelter homeless" and include those of the "street". It ought to be noted that shelter stay renders the homeless group unrepresentative for most of the people affected by the problem of homelessness. dalszych badań zależności „wsparcie a jakość życia” wśród osób bezdomnych. Dla przykładu badania z 2015 r. pokazały, że poprawa jakości życia u osób bezdomnych uzależnionych od alkoholu była związana z redukcją szkód zdrowotnych [41].

Inne są też predyktory jakości życia odnoszące się do zdrowia fizycznego - u bezdomnych poziom jakości życia w tym wymiarze wyznaczają głównie zmienne dotyczące uzależnienia od alkoholu (liczba drinków, dni picia, czas trwania uzależnienia), podczas gdy u osób leczonych stacjonarnie zmiennymi tymi okazały się dolegliwości somatyczne oraz poziom lęku.

Wyniki obu wymiarów - zdrowia fizycznego i psychicznego - przemawiają za bardziej ścisłym związkiem jakości życia z obrazem uzależnienia od alkoholu u bezdomnych w porównaniu z pacjentami stacjonarnymi. Namely i wsp. sugerują, że redukowanie picia alkoholu przyczynia się do poprawy jakości życia osób bezdomnych [41]. Oznacza to, że działania zmierzające do podwyższenia jakości życia w grupie bezdomnych powinny być ukierunkowane głównie na problemy dotyczące uzależnienia.

Uzyskane wyniki pokazały, że poprawa jakości funkcjonowania fizycznego i psychicznego osób uzależnionych od alkoholu leczonych stacjonarnie może nastąpić w wyniku działań terapeutycznych, w których należałoby po pierwsze diagnozować oraz redukować objawy depresyjne i lękowe, po drugie - minimalizować zaburzenia somatyczne zaraz po odstawieniu alkoholu [42]. Z kolei u osób bezdomnych poprawę tych samych komponentów jakości życia można byłoby uzyskać przez wczesne interwencje przerywające ciągi picia i optymalizację wsparcia społecznego [41].

Prezentowane badania mają też ograniczenia. Nie zapytano o czas trwania bezdomności, a ocena jakości życia dotyczyła ostatniego miesiąca przed badaniem - osoby bezdomne spędziły ten czas w hostelu lub schronisku. $Z$ kolei pacjenci podczas badania przebywali od trzech tygodni na oddziale odwykowym, co mogło ostateczne wpłynąć na ocenę zdrowia psychicznego i fizycznego oraz ocenę poziomu jakości życia. Ograniczeniem jest również liczba badanych osób, zwłaszcza bezdomnych. Jak się wydaje, warto podjąć dalsze badania na większej grupie bezdomnych „schroniskowych” i włączyć do badań bezdomnych „z ulicy”. Należy bowiem zaznaczyć, że pobyt w placówkach „schroniskowych” czyni grupę tych bezdomnych niereprezentatywną dla ogółu osób dotkniętych problemem bezdomności. 


\section{- Conclusions}

Alcohol dependent persons: shelter homeless or those staying at hostels and rehab inpatients similarly assess the quality of their lives in most of the studied areas of functioning on the SF-36 scale. The homeless persons rated their mental functioning better than the rehab inpatients.

The smaller number of experienced physical and anxiety disorders reported by inpatients may have had an influence on their higher quality of physical functioning results, and among the homeless, this was mainly a reduction in alcohol related behaviour (cutting down the alcoholic binges and time in dependency).

The better mental functioning of rehab inpatients depends on reduction of depression, anxiety and other mental disorder symptoms, similarly to the homeless, with which this is also paradoxically linked to limitation of social support.

\section{- WNIOSKI}

Osoby uzależnione od alkoholu - bezdomni przebywający w schronisku lub w hostelu oraz pacjenci leczeni stacjonarnie odwykowo - podobnie oceniają jakość swojego życia w większości badanych obszarów funkcjonowania w skali SF-36. Osoby bezdomne lepiej oceniały swoje funkcjonowanie psychiczne niż pacjenci leczeni stacjonarnie odwykowo.

Na wyższą jakość funkcjonowania fizycznego u pacjentów leczonych stacjonarnie może mieć wpływ mniejsza liczba doświadczanych zaburzeń somatycznych i lękowych, a u osób bezdomnych głównie redukcja zachowań związanych z alkoholem (skrócenie ciągów picia i czasu trwania uzależnienia).

Lepsze funkcjonowanie psychiczne pacjentów oddziału odwykowego zależy od redukcji objawów depresyjnych, lękowych i innych zaburzeń psychicznych, podobnie jak u osób bezdomnych, u których paradoksalnie jest dodatkowo związane $\mathrm{z}$ ograniczeniem wsparcia społecznego.

\section{Conflict of interest/Konflikt interesów}

None declared./Nie występuje.

\section{Financial support/Finansowanie}

The study was financed from the Nicolaus Copernicus University grant for young scientists (no 22/2008)./Badania finansowano z grantu Uniwersytetu im. Mikołaja Kopernika w Toruniu dla młodych naukowców (nr 22/2008).

\section{Ethics/Etyka}

The work described in this article has been carried out in accordance with the Code of Ethics of the World Medical Association (Declaration of Helsinki) on medical research involving human subjects, EU Directive (210/63/EU) on protection of animals used for scientific purposes, Uniform Requirements for manuscripts submitted to biomedical journals and the ethical principles defined in the Farmington Consensus of 1997.

Treści przedstawione w pracy są zgodne z zasadami Deklaracji Helsińskiej odnoszącymi się do badań z udziałem ludzi, dyrektywami EU dotyczącymi ochrony zwierząt używanych do celów naukowych, ujednoliconymi wymaganiami dla czasopism biomedycznych oraz z zasadami etycznymi określonymi w Porozumieniu z Farmington w 1997 roku.

The Bioethics Commission of the Collegium Medicum granted permission for the study (no KB/545/2007)./ Na badania uzyskano zgodę Komisji Bioetycznej Collegium Medicum (no KB/545/2007).

\section{References/Piśmiennictwo}

1. Marmorstein NR. Longitudinal associations between alcohol problems and depressive symptoms: early adolescence through early adulthood. Alcohol Clin Exp Res 2009; 33(1): 49-59.

2. Grant BF, Dufour MC, Harford TC. Epidemiology of alcoholic liver disease. Semin Liver Dis 1988; 8(1): 12-25.

3. Świątkowski M, Budzyński J, Kłopocka M, Pulkowski G, Ziółkowski M. Ciśnienie tętnicze w sześciomiesięcznej obserwacji mężczyzn uzależnionych od alkoholu leczonych odwykowo. Valetudinaria 2005; 10(2): 17-23. 
4. Yedlapati SH, Mendu A, Stewart SH. Alcohol-related diagnoses and increased mortality in acute myocardial infarction patients: An analysis of the nationwide inpatient sample. J Hosp Med 2016; 11(8): 563-7.

5. Li YY, Zhou JY. Role of lipin-1 in the pathogenesis of alcoholic fatty liver disease. Zhonghua Gan Zang Bing Za Zhi 2016; 24(3): 237-40.

6. Lahmek P, Berlin I, Michel L, Berghout C, Meunier N, Aubin HJ. Determinants of improvement in quality of life of alcohol-dependent patients during an inpatient withdrawal programme. Int J Med Sci 2009; 6(4): 160-7.

7. François C, Rahhali N, Chalem Y, Sørensen P, Luquiens A, Aubin HJ. The Effects of as-Needed Nalmefene on Patient-Reported Outcomes and Quality of Life in Relation to a Reduction in Alcohol Consumption in AlcoholDependent Patients. PLoS One 2015; 10(6): e0129289.

8. Wenzel SL, Burnam MA, Koegel P, Morton SC, Miu A, Jinnett KJ, et al. Access to inpatient or residential substance abuse treatment among homeless adults with alcohol or other drug use disorders. Med Care 2001; 39(11): 1158-69.

9. Stelcer B. Jakość życia jako pojęcie subiektywne i wielowymiarowe. Pielęgniarstwo Polskie 2001; 2(12): 227-33.

10. Reaney MD, Martin C, Speight J. Understanding and Assessing the Impact of Alcoholism on Quality of Life. A Systematic Review of the Content. Validity of Instruments Used to Assess Health-Related Quality of Life in Alcoholism. Patient 2008; 1(3): 151-63.

11. Frischknecht U, Sabo T, Mann K. Improved drinking behaviour improves quality of life: a follow-up in alcoholdependent subjects 7 years after treatment. Alcohol Alcohol 2013; 48(5): 579-84.

12. Schipper HL, Clinch JJ, Olweny CLM. Quality of life studies: definitions and conceptual issues. Quality of life and pharmacoeconomics in clinical trials. $2^{\text {nd }}$ ed. Philadelphia: Lippincott-Raven; 1996.

13. Uchmanowicz I, Łoboz-Grudzień K. Jakość życia - definicje i narzędzia badawcze - przegląd literatury. Fam Med Primary Care Rev 2008; 10(2): 245-52.

14. Przemeński A. Aktualny stan problemu bezdomności w Polsce. Aspekt polityczno-społeczny. In: Dębski M, Stachura K (eds.). Oblicza bezdomności. Gdańsk: Wydawnictwo Uniwersytetu Gdańskiego; 2008, p. 18.

15. Chodkiewicz J. Terapia osób uzależnionych od alkoholu: lęk i depresja a zasoby osobiste. Alkohol Narkom 2010; 23(3): 201-16.

16. Schanzer B, Dominguez B, Shrout PE, Caton CLM. Homelessness, Health Status, and Health Care Use. Am J Public Health 2007; 97(3): 464-9.

17. Karpyak VM, Biernacka JM, Geske JR, Abulseoud OA, Brunner MD, Chauhan M, et al. Gender-specific effects of comorbid depression and anxiety on the propensity to drink in negative emotional states. Addiction 2016; 111(8): 1366-75.

18. World Health Organization. The ICD-10 Classification of Mental and Behavioural Disorders. Clinical Descriptions and Diagnostic Guidelines. Available from: http://www.who.int/classifications/icd/en/bluebook.pdf?ua=1

19. McDowell I, Newell C. Measuring Health: A Guide to Rating Scales and Questionnaires. New York, London: Oxford University Press, 1996.

20. McHorney CA, Ware JE, Lu JF, Sherbourne CD. The MOS 36-item Short-Form Health Survey (SF-36): III. Tests of data quality, scaling assumptions, and reliability across diverse patient groups. Med Care 1994; 32(1): 40-66.

21. Ware J, Sherbourne C. The MOS 36-Item Short-Form Health Survey (SF-36): I. Conceptual Framework and Item Selection. Med Care 1992; 30(6): 473-83.

22. Luquiens A, Reynaud M, Falissard B, Aubin HJ. Quality of life among alcohol dependent patients: how satisfactory are the available instruments? A systematic review. Drug Alcohol Depend 2012; 125(3): 192-202.

23. Żołnierczyk-Zreda D, Wrześniewski K, Bugajska J, Jędryka-Góral A. Polska wersja kwestionariusza SF-36v2 do badania jakości życia. Warszawa: Centralny Instytut Ochrony Pracy - Państwowy Instytut Badawczy; 2009.

24. Beck A, Ward C, Mendelson M, Mock J, Erbaugh J. An inventory for measuring depression. Arch Gen Psychiatry 1961; 4(6): 561-71.

25. Parnowski T, Jernajczyk W. Skala Depresji Becka do oceny nastroju u osób zdrowych i u pacjentów z zaburzeniami afektywnymi. Psychiatr Pol 1977; 11(4): 417-21.

26. Folstein MF, Folstein SE, McHugh PR. "Mini-mental state“. A practical method for grading the cognitive state of patients for the clinician. $J$ Psychiatr Res 1975; 12(3): 189-98.

27. Jóźwiak A. Otępienie u osób w wieku starszym. Geriatria 2008; 2: 237-46.

28. Lipczyński A. Normalizacja State-Trait Anxiety Inventory (STAI) i możliwość jego stosowania w terapii osób uzależnionych od alkoholu. Psychologia.net.pl, 1997. Available from: http://www.psychologia.net.pl/artykul.php?level $=13$

29. Sosnowski T, Wrześniewski K, Jaworowska A, Fecenec D. Inwentarz Stanu i Cechy Lęku STAI. Polska adaptacja STAI. Podręcznik, wydanie 3. Warszawa: Pracownia Testów Psychologicznych Polskiego Towarzystwa Psychologicznego; 2006. 
30. Ziółkowski M. Ocena skuteczności farmakoterapii w zapobieganiu nawrotowi picia u mężczyzn uzależnionych od alkoholu. Bydgoszcz: Wydawnictwo Akademii Medycznej im. Ludwika Rydygiera; 1999.

31. Chodkiewicz J, Ziółkowski M, Czarnecki D, Markowska A, Augustyńska B, Opozda K. Zastosowanie Inwentarza związanego z Piciem (IDS) oraz Kwestionariusza Radzenia sobie w Sytuacjach Ryzykownych (SCQ) w badaniach osób uzależnionych od alkoholu. Doniesienia wstępne. Alkohol Narkom 2009; 22(3): 271-85.

32. Daeppen JB, Krieg MA, Burnand B, Yersin B. MOS-SF-36 in Evaluating Health-Related Quality of Life in Alcohol- Dependent Patients. Am J Drug Alcohol Ab 1998; 24(4): 685-94.

33. Malet L, Llorca PM, Beringuier B, Lehert P, Falissard B. ALQOL 9 for measuring quality of life in alcohol dependence. Alcohol Alcohol 2006; 41(2): 181-7.

34. Chodkiewicz J. Ocena jakości życia alkoholików przed i po terapii odwykowej. Co zmienia się w czasie leczenia? Alkohol Narkom 2012; 25(2): 133-50.

35. Usherwood T, Jones N. Self-perceived health status of hostel residents: use of the SF-36D health survey questionnaire. J Public Health 1993; 15(4): 311-4.

36. Volk RJ, Cantor SB, Steinbauer JR, Cass AR. Alcohol use disorders, consumption patterns, and health-related quality of life of primary care patients. Alcohol Clin Exp Res 1997; 21(5): 899-905.

37. Levola J, Aalto M, Holopainen A, Cieza A, Pitkänen T. Health-related quality of life in alcohol dependence: a systematic literature review with a specific focus on the role of depression and other psychopathology. Nord J Psychiatry 2014; 68(6): 369-84.

38. Barnes AJ, Xu H, Tseng CH, Ang A, Tallen L, Moore AA, et al. The Effect of a Patient-Provider Educational Intervention to Reduce At-Risk Drinking on Changes in Health and Health-Related Quality of Life Among Older Adults: The Project SHARE Study. J Subst Abuse Treat 2016; 60: 14-20.

39. Kertesz S, Larson M, Horton N, Winter M, Saitz R, Samet J. Homeless Chronicity and Health-Related Quality of Life Trajectories Among Adults with Addictions. Med Care 2005; 43(6): 574-85.

40. Warren JI, Stein JA, Grella ChE. Role of social support and self-efficacy in treatment outcomes among clients with co-occurring disorders. Drug Alcohol Depend 2007; 89(2-3): 267-74.

41. Collins SE, Grazioli VS, Torres NI, Taylor EM, Jones CB, Hoffman GE, et al. Qualitatively and quantitatively evaluating harm-reduction goal setting among chronically homeless individuals with alcohol dependence. Addict Behav 2015; 45: 184-90.

42. Ugochukwu C, Bagot KS, Delaloye S, Pi S, Vien L, Garvey T, et al. The importance of quality of life in patients with alcohol abuse and dependence. Harv Rev Psychiatry 2013; 21(1): 1-17. 
